From the results, curves for maximum probable availability are deduced. The suggestion is made that 'operating efficiency' should be calculated on a uniform basis and included in station records. The need for an overall standard by which the performance of generating stations can be judged is discussed, and the term 'standard merit', based upon operating efficiency and plant availability, is suggested.

It is concluded from the analysis that pre-1930 plant should not be operated at above 45 per cent average running plant load-factor if good availability is to be consistently maintained; marked improvements are to be noted in availability of the most recent plant installed since 1938 at 80 per cent average running plant load-factor ; the lower breakdown rate per plant item of the pre-1930 group is notable when compared with that of the later plant groups. Good quality and grading of fuel supplies are needed, particularly for the pre-1930 plant, if maximum outputs are to be obtained. With larger units of plant, greater outputs between breakdowns have been possible; but it is not safe to conclude that larger units still would be to the general benefit of the supply industry. Size of unit required is related to the load curves and security needs.

\section{Economic Rating of Motors and Transformers}

IN a paper read by Mr. D. J. Bolton before the Institution of Electrical Engineers on December 2, physical and economic ratings of motors and transformers respectively are compared, and the scope and limits of economic choice are discussed and illustrated. A method of economic selection is proposed through the use of larger standard machines, and a technique is developed for investigating the economy of changes in rating. Tables of data and results are given at the end of the paper, and the methods employed in these tables are explained in some detail. The results are expressed in the form of an 'economic advantage' obtainable through under-running or overrunning, and show the former to be highly advantageous in a large number of cases. Methods of implementing the results are discussed.

\section{Canadian Mortality in War Years}

According to an annotation in the September issue of the Statistical Bulletin, the health of the Canadian people has remained at a very favourable level during the four years of the present War, the mortality in this period being the lowest on record. The improvement in mortality has been particularly marked in the diseases most prevalent among the young. Not only has the death-rate decreased among the communicable diseases of childhood, but also there has been an increased fall in the mortality among the large number of young adults in training camps. Diarrhoea and enteritis, which have always been important causes of death among Canadian children, have also shown considerable improvement in recent years. The rate of decline in tuberculosis is illustrated by a new minimum of $47 \cdot 1$ per 100,000 , which is about one fifth below that for the period 1934-36. In contrast with the catastrophic influenza epidemic towards the close of the War of 1914-18, there has so far been no cause for serious concern, although there was a mild epidemic of influenza in Canada late in 1940 and early the following year, the favourable result being mainly due to the use of serum and chemotherapy in the treatment of pneumonia.
Chemotherapy has also succeeded in reducing the mortality from appondicitis and the diseases incidental to child-bearing. On the other hand, there has been an increase in the mortality from cancer, diabetes, diseases of the heart and arteries, and from accidents.

\section{Announcements}

Prof. A. R. Todn, Sir Samuel Hall professor of chemistry in the University of Manchester, has been appointed professor of organio chemistry in the University of Cambridge.

Prof. Anton J. Carlson, chairman of the Dəpartmont of Physiology in the University of Chicago, has been elected president of the American Association for the Advancement of Science.

TeE title of professor emeritus of bacteriology in the University of London has been conferred on Sir John Ledingham, on his retirement from the professorship of bacteriology at the Lister Institute of Preventive Medicine. The degree of D.Sc. has been conferred on Mr. B. Prasad (University College), Dr. E. C. Barton-Wright (Birkbeck College and Chelsea Polytechnic), Mr. A. G. McDonnell Weddell (St. Bartholomew's Hospital Medical College), and Mr. George King.

The Edison Medal for 1943 of the American Institute of Electrical Engineers, one of the highest honours in the field of electrical science and engineering, has been awarded to Dr. Vannevar Bush, president of the Carnegie Institution of Washington and director of the Office of Scientific Research and Development of the U.S. Office of Emergency Management, "for his contribution to the advancement of electrical engineering, particularly through the development of new applications of mathematics to engineering problems, and for his eminent service to the nation in guiding the war research program". Dr. Bush has also just received the Holly Medal of the American Society of Mechanical Engineers, for his work as a leader of engineering education and in scientific research, and in particular for his work on calculating machines.

OwING to the generosity of the Rockefeller Foundation of New York, which has for the fourth year in succession provided a grant for the purpose, the Royal Society is in a position to give some assistance to scientific societies and associations which, as a result of war conditions, are experiencing financial difficulties in the publication of scientific journals.

The following appointments to the Colonial Service have recently been made: E. Dixon to be veterinary officer, Nigeria; W. J. J. Filkins to be physiological laboratory superintendent, Uganda; J. S. Groome to be forest officer (temporary), Tanganyika; G. W.P. Streeton to be deputy government chemist, Jamaica.

Errata.-We are asked by Dr. A. Hunter to make it clear that the experiments on exposure-time effects in photographic photometry attributed to him in NATURe of February 26, p. 242, were planned and carried out by Prof. W. M. H. Greaves, Astronomer Royal for Scotland. Furthermore, the microphotometers he described at the symposium give intensity traces direct, not merely density records, as stated. 